\title{
PRENATAL DIAGNOSIS OF HAEMOPHILIA BM
}

\author{
Akira Yoshioka, ${ }^{1}$ Yoshiaki OHKubo, ${ }^{1}$ Toshiyuki SakaI, ${ }^{1}$ \\ Hiromu Fukui, ${ }^{1}$ Tadashi KamiYa,${ }^{2}$ Mitsuhiko Koresawa, ${ }^{3}$ \\ Akira MAtsui, ${ }^{4}$ and Takeshi Matsuda ${ }^{5}$ \\ ${ }^{1}$ Department of Paediatrics, Nara Medical College, \\ Kashihara, Nara 634, Japan \\ ${ }^{2}$ Department of 1 st Internal Medicine, Nagoya University School of Medicine, \\ Showa-ku, Nagoya 466, Japan \\ ${ }^{3}$ Department Obstetrics and Gynecology, Institute of Clinical Medicine, \\ The University of Tsukuba, Nithari-gun, Ibaraki 305, Japan \\ ${ }^{4}$ Paediatric Clinic, Isesaki Municipal Hospital, Isesaki, \\ Gunma 372, Japan \\ ${ }^{5}$ Depariment of Anatomy 1, Faculty of Medicine, \\ Toyama Medical and Pharmacentical University, \\ Toyama 930-01, Japan
}

\begin{abstract}
Summary Accurate mid-trimester prenatal diagnosis was achieved in a Japanese haemophilia BM family. At 21 weeks of gestation, liver blood from the male fetus at $50 \%$ risk was sampled using a needle guided by ultrasound. F.IX (F.IX:C and F.IX:Ag) and ox-brain PT in the fetal plasma were low and prolonged, but within the normal range of controls at mid-trimester. Pregnancy went to term and woman gave birth to an unaffected male. Haemophilia BM can be diagnosed in the mid-trimester of pregnancy by determination of F.IX:C, F.IX:Ag and ox-brain PT in pure fetal plasma.
\end{abstract}

Key Words prenatal diagnosis, haemophilia BM, factor IX, ox-brain prothrombin time, fetal blood sampling

\section{INTRODUCTION}

First-trimester prenatal diagnosis of haemophilia B is now possible by analyzing directly DNA in chorionic villi at 8-10 weeks of gestation (Williamson et al., 1981) using restriction fragment length polymorphisms (RFLPs) associated with the factor IX gene (Graham et al., 1985). This technique, however, can not be applied to Japanese haemophilia B relatives, because no RFLPs of the factor IX 
gene have been found in normal Japanese DNA samples when using intragenic F.IX probes (Kojima et al., 1987; Mikami et al., 1987).

Another technique of prenatal diagnosis even in Japanese haemophilia B families is determination of the factor IX level in plasma obtained from the fetus at 18-22 weeks of gestation (Mibashan et al., 1979; Holmberg et al., 1980). However, the factor IX antigen (F.IX:Ag) level assayed by current immunological methods is not applicable to fetal diagnosis of haemophilia $\mathrm{B}^{+}$genetic types characterized by the presence of cross-reacting material $\left(\mathrm{CRM}^{+}\right)$(Holmberg and Ljung, 1982).

We describe here the prenatal diagnosis of Japanese haemophilia BM, a haemophilia $\mathrm{B}^{+}$variant having an abnormal reaction with ox-brain thromboplastin (Hougie and Towmey, 1967). This is the first reported case of prenatal diagnosis of haemophilia BM.

\section{METHODS}

Assays of F.IX. Factor IX clotting activity (F.IX:C) was assayed as kaolinactivated partial thromboplastin time (K-PTT) in immuno-depleted F.IX deficient plasma (Nishimura et al., 1986) using 3A6 anti-FIX monoclonal antibody (Yoshioka et al., 1985). Ox-brain prothrombin time (PT) was determined by the method of Quick et al. (1935). Laurell's electroimmunoassay (EIA) for factor IX antigen (F.IX:Ag) was performed using a rabbit antibody (Fukui et al., 1981). A two-site solid phase enzyme-linked immunosorbent assay (ELISA) was developed using monoclonal antibody 3A6 to quantitate F.IX:Ag (Yoshioka et al., 1985).

Normal pooled-plasma obtained from 10 normal donors was used as reference material. One unit is the amount of F.IX in $1 \mathrm{ml}$ normal pooled-plasma.

Controls of fetal plasma. Control values of plasma F.IX:C, F.IX:Ag and ox-brain PT were determined in pure fetal blood (19-20 weeks of gestation) from 10 control fetuses, including 3 male fetuses at $50 \%$ risk for haemophilia $\mathrm{A}$, aborted for therapeutic reasons because of other genetic disorders.

Case. The propositus, a 3-year-old boy, had easy bruising and epistaxis since his infant period. He had an overt haemorrhage from hard palate after a small injury at the age of 10 months, when a diagnosis of haemophilia B (F.IX:C $5 \mathrm{u} / \mathrm{dl}$ ) was made at Dokkyo Medical College. At the age of 3 years, haemostatic findings in the patient was re-evaluated at the Department of Paediatrics, Nara Medical College, and the diagnosis of haemophilia BM (Kiryu) was established (Yoshioka et al., 1987) (Table 1).

The 29-year-old mother of the propositus was considered to be a carrier due to low level of F.IX:C $(30-40 \mathrm{u} / \mathrm{dl})$ at the same time when the propositus was diagnosed as having haemophilia B. She became pregnant ( 7 weeks of gestation) and was unwilling to bear a haemophilic son. She visited a genetic counsellor (Dr. A. Matsui) for prenatal diagnosis of the fetus.

The level of F.IX:C and F.IX:Ag in the woman (11 weeks) was $90 \mathrm{u} / \mathrm{dl}$ and 
Table 1. Haemostatic findings of the propositus and his mother.

\begin{tabular}{lccc}
\hline & $\begin{array}{c}\text { F.IX:C } \\
(\mathrm{u} / \mathrm{d})\end{array}$ & $\begin{array}{c}\text { F.IX:Ag } \\
(\mathrm{u} / \mathrm{d})\end{array}$ & $\begin{array}{c}\text { Ox-brain PT } \\
\text { (sec) }\end{array}$ \\
\hline $\begin{array}{l}\text { Propositus (Haemophilia BM (Kiryu) } \\
\text { Mother of the propositus }\end{array}$ & 2.5 & 100 & $126(57)^{\mathrm{a}}$ \\
$\quad$ at non-pregnant state & $30-40$ & ND $^{b}$ & ND $^{b}$ \\
at 11 weeks of pregnancy & 90 & 100 & $79(57)$ \\
6 months after delivery & 58 & 100 & $72(53)$ \\
\hline
\end{tabular}

${ }^{a}$ ( ), normal control. ${ }^{b} \mathrm{ND}$, not determined. Normal range of F.IX:C and F.IX:Ag in normal subjects is $50-200 \mathrm{u} / \mathrm{dl}$.

$100 \mathrm{u} / \mathrm{d}$, respectively. Ox-brain PT was moderately prolonged (Table 1).

Prior to an amniocentesis, Southern bot analysis of the F.IX gene in the family (the propositus and his parents) was carried out (Mikami et al., 1987) using F.IX cDNA (cVII) kindly provided by Dr. G.G. Brownlee, Oxford, UK, and several kinds of endonucleases. Unfortunately, the F.IX RFLPs pattern in the family was not informative.

Then fetal sexing by amniocentesis was performed at 16 weeks of gestation. Chromosome analysis of the cultured fetal fibroblast in the amniotic fluid revealed a male karyotype, $46 \mathrm{XY}$.

Subsequently, fetal blood sampling was also performed at 21 weeks of gestation. Pure fetal blood from an intrahepatic vessel was obtained using a percutaneous transhepatic cholangiography (PTC) needle $(15 \mathrm{~cm}$ long and 23 gauge) under ultrasound guidance (Koresawa et al., 1987).

\section{RESULTS}

Control values of fetal plasma F.IX:C, FIX:Ag and ox-brain PT were determined (Table 2). The significant positive correlation between the levels of F.IX:C and F.IX:Ag supported the validity of the bioassays of these samples. By ultrasound guided percutaneous fetal sampling, a total of $1.5 \mathrm{ml}$ of anti-coagulated (1/10 volume of $3.8 \%$ sodium citrate) blood was obtained from the liver. The first $0.5 \mathrm{ml}$ of the whole blood (Sample 1) was over-diluted with anticoagulant and/or amniotic fluid, and had 15\% hematocrit (Hct). Sample $2(1.0 \mathrm{ml})$ had $35 \% \mathrm{Hct}$, which was in the expected range. Sample 1 was analyzed with a combined cell counter and cell size analyzer (Coulter Chanalizer), and found to be free of maternal blood contamination. Because, clear distinction between red cell size distribution curves of fetal blood (MCV 129.9 fl) and maternal control (MCV $94.3 \mathrm{fl}$ ) was obtained.

Both F.IX:C and F.IX:Ag in the fetal plasma (Sample 2) were low $(3.6 \mathrm{u} / \mathrm{dl}$ and $4.8 \mathrm{u} / \mathrm{dl}$, respectively) but remained within the normal range of controls at mid-trimester. Ox-brain PT was within the normal range, whereas ox-brain PT in the propositus was remarkably prolonged. 
Table 2. Haemostatic findings of the fetal plasma.

\begin{tabular}{lcccc}
\hline & $\begin{array}{c}\text { Hct } \\
(\%)\end{array}$ & $\begin{array}{c}\text { F.IX:C } \\
(\mathrm{u} / \mathrm{dl})\end{array}$ & $\begin{array}{c}\text { F.IX:Ag } \\
(\mathrm{u} / \mathrm{dl})\end{array}$ & $\begin{array}{c}\text { Ox-brain PT } \\
(\mathrm{sec})\end{array}$ \\
\hline $\begin{array}{l}\text { Fetal plasma of this case } \\
\quad \text { Sample 1 }\end{array}$ & 15 & 18.0 & 2.0 & $74(31.5)^{\mathrm{a}}$ \\
$\quad$ Sample 2 & 35 & 3.6 & 4.8 & $71(31.5)$ \\
$\quad \begin{array}{l}\text { Control fetal plasms (n=10) } \\
\quad \text { Mean }\end{array}$ & 35 & 6.8 & 6.2 & 73.2 \\
$\quad$ Range & $33-37$ & $3.5-12.0$ & $3.0-9.5$ & $62-89(45-57)$ \\
\hline
\end{tabular}

a ( ), normal control of ox-brain PT.

We speculated that the fetus did not have haemophilia BM because of the normal level of F.IX and normal ox-brain PT. The woman decided to go to term. At full-term she gave birth to a male whose F.IX:C and F.IX:Ag in the cord were $55 \mathrm{u} / \mathrm{dl}$ and $30 \mathrm{u} / \mathrm{dl}$, respectively. At $10 \mathrm{hr}$ and at 6 months after birth, plasma F.IX and ox-brain PT in the baby was redetermined, and it was confirmed that he did not have haemophilia $B$.

\section{DISCUSSION}

Since haemophilia BM is characterized by $\mathrm{CRM}^{+}$and prolonged ox-brain PT, the determination of F.IX:Ag alone in the fetal plasma is meaningless. Moreover, evaluation of the results of F.IX assay and ox-brain PT may be hampered by contamination of the sample with maternal blood and/or amniotic fluid, which contains F.IX:Ag and thromboplastin-like material (Holmberg et al., 1980; Bertina et al.. 1981; Thompson, 1984).

Table 2 shows the reference values of F.IX:C and F.IX:Ag in mid-trimester in our laboratory. The mean value was $6.8 \mathrm{u} / \mathrm{dl}$ with a range of $3.5-12.0 \mathrm{u} / \mathrm{dl}$ and $6.2 \mathrm{u} / \mathrm{dl}$ with a range of $3.0-9.5 \mathrm{u} / \mathrm{dl}$, respectively. These data are similar to those reported by several authors (Mibashan et al., 1979; Holmberg et al., 1980; Terwiel et al., 1980; Bertina et al., 1981; Thompson, 1984). We successfully obtained 1.5 $\mathrm{ml}$ of pure fetal blood by ultrasound guided percutaneous liver sampling using a 23G PTC needle. Since Sample 1 (Hct 15\%) was diluted with anticoagulant and/or amniotic fluid, F.IX:C in the fetal plasma was thought to be estimated higher than it was. Both F.IX:C and F.IX:Ag in Sample 2, of which Hct $(35 \%)$ was in the expected range, were low but within normal range. We considered that F.IX:C in Sample 2 should be below $1 \mathrm{u} / \mathrm{dl}$ in case the fetus was affected. Moreover, ox-brain PT was within the normal range determined in our laboratory. We speculated that this moderate prolongation of the ox-brain PT in the fetus was due to low levels of factors II, VII and X in the mid trimester but not from abnormal F.IX (Terwiel et al., 1980; Forestier et al., 1985). From these results, we speculated the fetus did not have haemophilia BM. 
The pregnancy went to term uneventfully. The coagulation study confirmed that the newborn infant did not have haemophilia B. Neither any mark of cutaneous puncture nor subcutaneous haematoma was seen. The results of ultrasound tomography of the liver and blood chemistry were normal.

When we started fetal blood sampling through fetal liver, the most popular method of fetal blood sampling had been fetoscopy. When the attempt was failed by fetoscopy, however, we offered both parents another possibility of fetal blood sampling by liver puncture. Since it was the first our experience of this sort of approach, the operational risk could not be estimated. With informed consent and parents' request for fetal blood sampling in spite of its unknown risk, the liver puncture was performed (Koresawa et al., 1987).

Fetoscopic blood sampling did not show prolonged bleeding in utero even if the fetus is affected by haemophilia (Mibashan et al., 1979). The fact suggested that liver puncture would not cause extra haemorrhage in utero. Thereafter, we have detected no prolonged haemorrhage caused by fetal liver puncture even in affected cases (Koresawa et al., 1987).

Prenatal diagnosis of haemophilia B or even haemophilia BM is possible by determinations of F.IX:C, F.IX:Ag and ox-brain PT in pure fetal plasma obtained by percutaneous liver sampling. This is the first report on the prenatal diagnosis in a Japanese haemophilia B family.

Acknowledgement The present work was supported by a Grant-in-Aid for Scientific Research (No. 63480239) from the Ministry of Education, Science and Culture of Japan.

\section{REFERENCES}

Bertina, R.M., Aiderkamp, T.H.J., van der Linden, I.K., and van Tilburg, N.H. 1981. Use of coagulation assay in prenatal diagnosis of haemophilia A and B. Lancet i: 326.

Forestier, F., Daffos, F., Rainaut, M., Solé, Y., and Amiral, J. 1985. Vitamin K dependent proteins in fetal hemostasis at mid trimester of pregnancy. Thromb. Haemostas. 53: 401-403.

Fukui, H., Fujimura, Y., Shima, M., Sakai, T., Mikami, S., and Yoshioka, A. 1981. Partial proteolytic susceptibility to contact activation in hemophilia $\mathrm{B}^{+}$with slightly prolonged bovine brain prothrombin time. J. Nara Med. Assoc. 32: 526-536.

Graham, J.B., Green, P.P., McGraw, R.A., and Davis, L.M. 1985. Application of molecular genetics to prenatal diagnosis and carrier detection in the haemophilias: Some limitation. Blood 66: 759-764.

Holmberg, L., Gustavii, B., Cordesius, E., Kristoffersson, A-C., Ljung, R., Löfberg, L., Strömberg, P., and Nilsson, I.M. 1980. Prenatal diagnosis of hemophilia B by an immunoradiometric assay of factor IX. Blood 56: 397-401.

Holmberg, L. and Ljung, R. 1982. Limitation of VIII:CAg and IX:Ag determinations in prenatal diagnosis. In The Proceedings of 3 rd International Symposium on Hemophilia Treatment, Abe, T., ed., Kyoritsu Printing, Tokyo, pp. 103-106.

Hougie, C. and Towmey, J.J. 1967. Haemophilia BM: A new type of factor-IX deficiency. Lancet i: $698-700$.

Kojima, T., Tanimoto, M., Kamiya, T., Obata, Y., Takahashi, T., Ohno, R., Kurachi, K., and Saito, H. 1987. Possible absence of common polymorphisms in coagulation factor IX gene in Japanese subjects. Blood 69: 849-352. 
Koresawa, M., Inaba, J., and Iwasaki, H. 1987. Fetal blood sampling by liver puncture. Acta Obstet. Gynaec. Jpn. (in Japanese) 39: 395-399.

Mibashan, R.S., Rodeck, C.H., Thumpston, J.K., Edwards, R.J., Singer, J.D., and White, J.M. 1979. Plasma assay of fetal factors VIIIC and IX for prenatal diagnosis of haemophilia. Lancet ii: $1309-1311$.

Mikami, S., Nishino, M., Nishimura, T., and Fukui, H. 1987. RFLPs of factor IX gene in Japanese haemophilia B families and gene deletion in two high-responder-inhibitor patients. $J p n . J$. Human Genet. 32: 21-31.

Nishimura, T., Ohkubo, Y., Nishino, M., Sakai, T., Sawai, J., Tanaka, I., Takamiya, O., and Yoshioka, A. 1986. Preparation of factor IX deficient plasma by immunoadsorption using monoclonal antibody (3A6) to factor IX and its application. Jpn. J. Clin. Pathol. (in Japanese) 34: $469-474$.

Quick, A.J., Stanley-Brown, M., and Bancroft, F.W. 1935. A study of the coagulation defect in hemophilia and in jaundice. Am. J. Med. Sci. 190: 501-511.

Terwiel, J.Ph., Veltkamp, J.J., Bertina, R.M., and Muller, H.P. 1980. Coagulation factor in human fetus of about 20 weeks of gestation age. Br. J. Haematol. 45: 641-650.

Thompson, A.R. 1984. Factor IX and prothrombin in amniotic fluid and fetal plasma: Constraints on prenatal diagnosis of hemophilia B and evidence of proteolysis. Blood 64: 867-874.

Williamson, R., Eskdale, J., Coleman, D.V., Niazi, M., Loeffer, F.E., and Modell, B.M. 1981. Direct gene analysis of chorionic villi: a possible technique for first-trimester antenatal diagnosis of haemoglobinopathies. Lancet ii: $1125-1127$.

Yoshioka, A., Giddings, J.C., Thomas, J.E., Fujimura, Y., and Bloom, A.L. 1985. Immunoassays of factor IX antigen using monoclonal antibodies. Br. J. Haematol. 59: 265-275.

Yoshioka, A., Sakai, T., Yamamoto, K., Ohkubo, Y., and Fukui, H. 1987. A simple method for analyzing factor IX activation in the patients with hemophilia B variants. Thromb. Haemostas. 58: 705-708. 